\title{
Prey identification in nests of the potter wasp Hypodynerus andeus (Packard) (Hymenoptera, Vespidae, Eumeninae) using DNA barcodes
}

\author{
Héctor A. Vargas ${ }^{1,4}$, Marcelo Vargas-Ortiz², Wilson Huanca-Mamani² \& Axel Hausmann ${ }^{3}$
}

\begin{abstract}
'Departamento de Recursos Ambientales, Facultad de Ciencias Agronómicas, Universidad de Tarapacá, Casilla 6-D, Arica, Chile. ${ }^{2}$ Departamento de Producción Agrícola, Facultad de Ciencias Agronómicas, Universidad de Tarapacá, Arica, Chile. ${ }^{3}$ Entomology Department, SNSB/ZSM, Zoological Collection of the State of Bavaria, Munich, Germany.

${ }^{4}$ Corresponding author. havargas@uta.cl
\end{abstract}

\begin{abstract}
Prey identification in nests of the potter wasp Hypodynerus andeus (Packard) (Hymenoptera, Vespidae, Eumeninae) using DNA barcodes. Geometrid larvae are the only prey known for larvae of the Neotropical potter wasp Hypodynerus andeus (Packard, 1869) (Hymenoptera, Vespidae, Eumeninae) in the coastal valleys of the northern Chilean Atacama Desert. A fragment of the mitochondrial gene cytochrome oxidase c subunit 1 was amplified from geometrid larvae collected from cells of $H$. andeus in the Azapa Valley, Arica Province, and used to provide taxonomic identifications. Two species, Iridopsis hausmanni Vargas, 2007 and Macaria mirthae Vargas, Parra \& Hausmann, 2005 were identified, while three others could be identified only at higher taxonomic levels, because the barcode reference library of geometrid moths is still incomplete for northern Chile.
\end{abstract}

KEYWORDS. Boarmiini; Cyclophorini; Geometridae; Insecta; Neotropical.

The animal DNA barcode is a short, standardized region of the cytochrome c oxidase subunit 1 (COI) gene proposed as the core of a DNA-based identification system (Hebert et al. 2003a). DNA barcoding provides a very useful tool for species identification and species delimitation (Hebert et al. 2003b, 2010; Dincã et al. 2011; Goldstein \& DeSalle 2011; Teletchea 2010; Hausmann et al. 2011, 2013; Puillandre et al. 2011; Strutzenberger et al. 2011; Mutanen et al. 2012; Laiho \& Ståhls 2013; Nagy et al. 2013), and is especially valuable for associating extreme forms, sexes and different stages of the life cycle of organisms (Miller et al. 2005; Hausmann \& Parra 2009; Silva-Brandão et al. 2009; Jinbo et al. 2011; Li et al. 2011). DNA barcodes may be potentially useful for studying trophic links in complex field scenarios (Valentini et al. 2009), as in the case of webs involving host-parasitoid interactions, where many times host identification must be performed using immature stages (Hrcek et al. 2011).

Potter wasps (Hymenoptera, Vespidae, Eumeninae) are primarily solitary hunters, with some species having primitively social behavior (West-Eberhard 2005). Although nesting habits are variable among potter wasps, and various types of substrata may be used for nest construction, mud is broadly employed. Each nest is composed of one or more cells, into which the female lays one egg and a number of prey, which are eaten by the wasp larva after eclosion (e.g., Matthews \& González 2004; Matthews \& Matthews 2009). Thus, a detailed knowledge of the prey spectrum used by the potter wasps is important to understand their field biology (Chiappa \& Rojas 1991; Sears et al. 2001; Budriene 2003). This information may be useful in order to design ecological studies or to plan the conservation of these species.
The Neotropical potter wasp genus Hypodynerus de Saussure, 1855 is mostly associated with the Andes from Colombia to southern Chile (Willink 1970; Carpenter \& Garcete-Barrett 2002; Garcete-Barrett \& Hermes 2013). Although this genus is represented by thirty species in Chile (Barrera-Medina 2011), their nesting biology is poorly documented, and accurate prey identification at species level is not available (Claude-Joseph 1930; Pérez-D’Angello 1968, 1974, 1991; Méndez-Abarca et al. 2012).

Hypodynerus andeus (Packard, 1869) is known from Ecuador, Peru and Chile (Willink 1970). Larvae of the moth family Geometridae have been mentioned as the only prey for this potter wasp in the coastal valleys of the northern Chilean Atacama Desert (Méndez-Abarca et al. 2012). However, morphological identification of immature stages is rarely successful within Neotropical Lepidoptera, because their external morphology is still poorly known and often does not offer unambiguous differential features. Thus, the objective of this contribution is to identify prey larvae collected from nests of $H$. andeus using DNA barcodes.

\section{MATERIAL AND METHODS}

Specimen collection. Larvae were collected from three cells of $H$. andeus in January 2013 in the Azapa valley (18¹3'14"S,70¹0’42"W), Arica Province, northern Chile. Each cell was taken from a different nest, with maximum distance among nests of about $30 \mathrm{~m}$. The cells were not completely filled, as shown by the presence of a funnel-like structure surrounding the entrance orifice. This structure is generally removed when the cell is fully provisioned 
(Méndez-Abarca et al. 2012). All the prey larvae were taken from the respective cell and preliminarily identified as morphotypes (M1 to M6) based on combinations of external characters, color and relative size (Table I). Additionally, two male adults of Geometridae were collected at the light on the same date and site, which were identified as Iridopsis hausmanni Vargas, 2007 (voucher: IDEA-002-03-20; GenBank accession number: KF663057; 616 bp) and Macaria mirthae Vargas, Parra \& Hausmann, 2005 (voucher: IDEA-002-03-19; GenBank accession number: KF663056; 596 bp), based on morphological characters (Vargas 2007; Vargas et al. 2005).

Table I. Geometrid larvae collected and barcoded from cells of three nests of the Neotropical potter wasp Hypodynerus andeus (Packard) in the Azapa valley, northern Chilean Atacama Desert.

\begin{tabular}{cccccc}
\hline Morphotype & $\mathrm{n}$ & Nest & Voucher & $\begin{array}{c}\text { Sequence } \\
\text { lengt(bp) }\end{array}$ & $\begin{array}{c}\text { GenBank } \\
\text { Accession }\end{array}$ \\
\hline M1 & 3 & 1 & IDEA-002-03-2 & 658 & KF663044 \\
& & 1 & IDEA-002-03-3 & 639 & KF663045 \\
& & 2 & IDEA-002-03-14 & 658 & KF663053 \\
M2 & 5 & 1 & IDEA-002-03-6 & 658 & KF663046 \\
& & 1 & IDEA-002-03-7 & 581 & KF663047 \\
& & 1 & IDEA-002-03-8 & 581 & KF663048 \\
& & 2 & IDEA-002-03-11 & 658 & KF663051 \\
& & 2 & IDEA-002-03-12 & 578 & KF663052 \\
M3 & 1 & 1 & IDEA-002-03-9 & 658 & KF663049 \\
M4 & 1 & 1 & IDEA-002-03-10 & 658 & KF663050 \\
M5 & 1 & 3 & IDEA-002-03-15 & 658 & KF663054 \\
M6 & 1 & 3 & IDEA-002-03-16 & 658 & KF663055 \\
\hline
\end{tabular}

DNA extraction and sequencing. The two adults and fourteen larvae were used for DNA extraction with the Insect DNA Kit (Omega bio-tek) according to the manufacturer's instructions. Subsequently, a fragment of the COI gene was amplified by polymerase chain reaction (PCR) with the primers $\mathrm{LCO}$ 1490 5'-GGTCAACAAATCATAAAGATATTGG-3' and HCO 2198 5'-TAAACTTCAGGGTGACCAAAAAATCA-3', developed by Folmer et al. (1994). PCR reactions were performed in a final volume of $20 \mu \mathrm{l}$. Each reaction contained $1 \mu \mathrm{l}$ of DNA extract, 10 mmoles of each primer, $2,5 \mathrm{mM}$ of each dNTP, $2 \mathrm{mM} \mathrm{MgCl}{ }_{2}$, 1 X PCR buffer $(\mathrm{KCl}), 1$ unit of Taq DNA polymerase (Thermo Scientific) and sterile distilled water. Cycling conditions were: $5 \mathrm{~min}$ at $94^{\circ} \mathrm{C} ; 35$ cycles of $30 \mathrm{sec}$ at $94^{\circ} \mathrm{C} ; 30 \mathrm{sec}$ at $55^{\circ} \mathrm{C} ; 30 \mathrm{sec}$ at $72^{\circ} \mathrm{C}$ and final elongation step of $2 \mathrm{~min}$ at $72^{\circ} \mathrm{C}$. PCR blank reactions controls were incorporated. Three $\mu \mathrm{l}$ of each PCR product was visualized on 1.5\% agarose gel stained with gel-red (Biotium). Reactions containing fragments of the expected size were directly sequenced by a commercial facility (Macrogen, South Korea).

Data analysis. Sequences were edited and aligned using MEGA 5.05 (Tamura et al. 2011). Following Hebert et al. (2003a), sequence divergences were calculated using the Kimura-2-parameter method and a neighbor-joining tree was constructed with MEGA 5.05 (Tamura et al. 2011) based on these values. A search with the BOLD v.3 Identification System (Ratnasingham \& Hebert 2007) was performed for each sequence in order to identify larvae that did not match adults sequenced in this study. Five sequences of the genera Physocleora Warren, 1897, Pherotesia Schaus, 1901, Neodora Warren, 1897, Pantherodes Guenée, [1858] and Cyclophora Hübner, 1822, which resulted as nearest 'neighbors' when blasting the larval sequences are deposited in the public data project GZPUV on BOLD database where they can easily be accessed and downloaded (specimen ID's BC ZSM Lep 03021, 18780, 57455, 59014, 59120, respectively).

\section{RESULTS}

Overall, 578-658 base pairs (bp) of COI fragments were sequenced from fourteen individuals, including two adults and twelve larvae (Table I). Genetic distance among individuals was $0-15.6 \%$, suggesting that more than one species of geometrid was involved as prey of $H$. andeus among the samples. Six larval morphotypes (M1 to M6) were identified, among which only five DNA barcodes were recognized.

Six larvae (IDEA-002-03-6, IDEA-002-03-7, IDEA-00203-8, IDEA-002-03-10, IDEA-002-03-11 and IDEA-002-0312) shared their DNA barcode with the adult of $M$. mirthae (Fig. 1), at a genetic distance of $0.2-0.5 \%$. Five of these larvae were previously assigned to $\mathrm{M} 2$, which was characterized by a light green coloration with a white lateral stripe, while the remaining one was the only representative of M4, characterized by a pale grey coloration without a lateral stripe. One larva (IDEA-002-03-15), which was the only representative of M5, matched exactly the barcode of I. hausmanni (Fig. 1; aligned fragment length $616 \mathrm{bp}$ ).

Three other unidentified geometrid species were detected in the sample (Fig. 1). One was represented by three larvae (IDEA-002-03-2, IDEA-002-03-3 and IDEA-002-03-14); all of these were previously assigned to M1, with no variation along a fragment of $639 \mathrm{bp}$ length. Blasting that sequence on the BOLD database (with $>20,000$ sequences of Neotropical geometrids, belonging to $>5,000$ species covering almost all described genera) suggests it to be a member of the subfamily Ennominae. The nearest neighbor genera are from the tribe Boarmiini: Physocleora at $7.8 \%$ minimum distance (Kimura 2 parameter) and Pherotesia at $8.5 \%$ distance. Two other species were represented by one larva each: one (M6: IDEA-002-03-16) likely also belongs to Ennominae, nearest neighbor genera Neodora at a genetic distance of $4.7 \%$ and Pantherodes at a distance of 5.1\%; the other one (M3: IDEA002-03-9) to the Sterrhinae, tribe Cyclophorini, nearest neighbor Cyclophora nanaria (Walker, 1861) at a distance of $4.7 \%$.

\section{DISCUSSION}

The only previous report of DNA barcodes of Chilean Geometridae was performed for 87 species from the southern zone of this country, in which host plant relationships were revealed for some species based on barcodes of larvae and adults (Hausmann \& Parra 2009). This study reports the first DNA barcodes for the geometrid fauna from the north- 


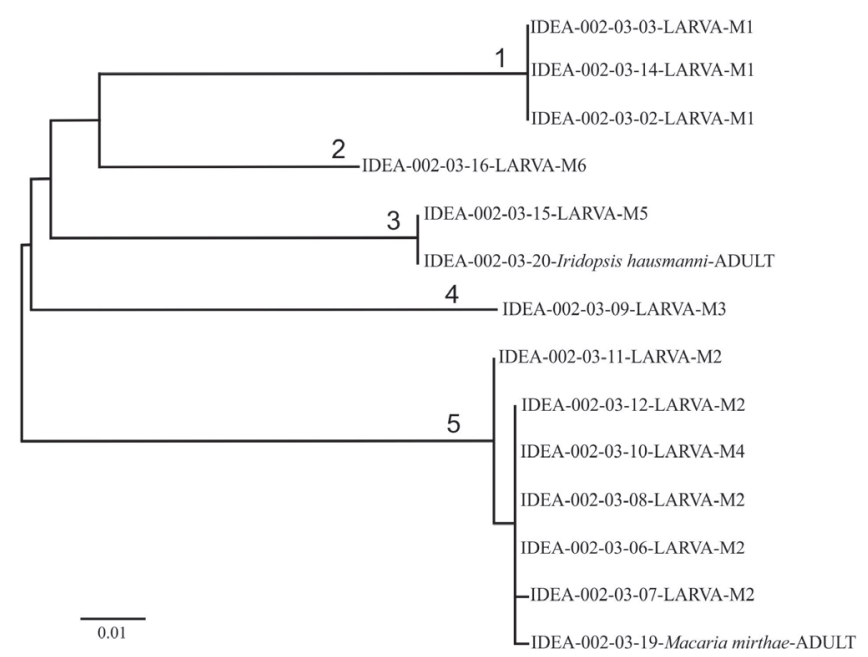

Fig. 1. Neighbor Joining tree of geometrid larvae collected in cells of Hypodynerus andeus wasps in the Azapa valley, Arica Province, northern Chile, and adults of Iridopsis hausmanni and Macaria mirthae from the same locality, based on $578 \mathrm{bp}$ of the barcoding region (cytochrome oxidase c subunit I gene (5'), COI). Numbers above branches indicate species: (1) Ennominae, Boarmiini, nearest neighbor genus Physocleora; (2) Sterrhinae, Cyclophorini, nearest neighbor Cyclophora nanaria; (3) I. hausmanni; (4) Ennominae, nearest neighbor genus Neodora; (5) M. mirthae.

ern Chilean Atacama Desert. Specifically, DNA barcodes were employed here to explore the prey spectrum of a potter wasp.

The number of prey species detected in this study was five (Fig. 1), all Geometridae. This fact confirms the specialization of $H$. andeus females in hunting geometrid larvae, as previously reported for the same locality based on morphological evidence (Méndez-Abarca et al. 2012). Interestingly, a high proportion $(50 \%)$ of the barcoded larvae matched with $M$. mirthae; however, four other species belonging to multiple genera were also detected in this study, suggesting that females of $H$. andeus are not prey specialist at species level. Even more, the capacity of the females of $H$. andeus for hunting more than one prey species could be an important factor underlying the presence of this potter wasp in many different environments in northern Chile, because the taxonomic composition and abundance levels of available prey must be different among places. Moreover, a significant variation in abundance levels of prey is also expected among seasons in some sites. Thus, identity and relative importance of each prey species in $H$. andeus nests should vary at geographic and temporal levels.

Although M. mirthae was already mentioned as a probable prey of $H$. andeus in this locality based on morphology (Méndez-Abarca et al. 2012), this is the first confirmation through DNA barcodes. The presence of $M$. mirthae in the cells may be related to the presence of some Fabaceae trees in the study site, which are used as hosts by the larvae of this species (Vargas et al. 2005). Similarly, one of the Anacardiaceae host plants used by I. hausmanni in the coastal valleys of the northern Chilean Atacama Desert was also present in the study site (Vargas 2014).
Macaria mirthae was represented by two morphotypes in the sample, which were clustered based on barcodes (Fig. 1 ); thus overestimation of the number of prey species was avoided by using barcodes in this study. Similarly, in other occasions geometrid larvae with the same two color patterns here reported for M. mirthae have been collected on Acacia macracantha Willd. in the same study site. The subsequent rearing of these larvae to adult stage has always revealed $M$. mirthae based on genitalia morphology (HAV, unpublished). Even more, it is known that identifications of geometrid larvae based only on external morphology may be unsatisfactory for two reasons: more than one larval morph may be present for each species (Bocaz et al. 2003; Vargas \& Parra 2013), or external morphological attributes may not be variable among different species (Grehan et al. 1994).

The results here reported on the prey of $H$. andeus constitute one more example highlighting the usefulness of DNA barcoding as an effective tool to be used in field ecology studies. A more detailed DNA barcode study of northern Chilean Geometridae, together with a better documentation of their host plant relationships, is necessary in order to clarify the trophic ecology of this potter wasp in this geographic area.

\section{ACKNOWLEDGEMENTS}

The authors would like to thank Gislene L. Gonçalves and Gilson R. P. Moreira, Universidade Federal do Rio Grande do Sul, and two anonymous referees for kind comments and suggestions on a preliminary version, and to Lafayette Eaton for kindly checking the English version. Financial support was obtained from project DGI-9710-13, Dirección General de Investigación, Universidad de Tarapacá. The equipment used to perform the molecular analysis was supported by Convenio de Desempeño-UTA-MECESUP-2.

\section{REFERENCES}

Barrera-Medina, R. 2011. Descripción de una nueva avispa alfarera del norte chico chileno, Hypodynerus anae n. sp. (Hymenoptera: Vespidae: Eumeninae). Boletín de la Sociedad Entomológica Aragonesa 48: 157-162.

Bocaz, P., Parra L.E. \& Victoriano, P.F. 2003. Larval morphological variation and its relation to host plants in Syncirsodes primata (Lepidoptera: Geometridae). Gayana 67: 3944.

Budriene, A. 2003. Prey of Symmorphus wasp (Hymenoptera: Eumeninae) in Lithuania. Acta Zoologica Lituanica 13: 306-310.

Carpenter, J.M. \& Garcete-Barrett, B.R. 2002. A key to the Neotropical genera of Eumeninae (Hymenoptera: Vespidae). Boletín del Museo Nacional de Historia Natural de Paraguay 14: 52-73.

Chiappa, E. \& Rojas, M. 1991. Observaciones en la nidificación de Pachodynerus peruensis (Saussure) (Hymenoptera: Vespidae: Eumeninae). Revista Chilena de Entomología 19: 45-50.

Claude-Joseph, F. 1930. Recherches biologiques sur les prédateurs do Chili. Annales de Sciencies Naturelles Zoologie 10: 235-354.

Dincã, V., Zakharov, E.V., Hebert, P.D.N. \& Vila, R. 2011. Complete DNA barcode reference library for a country's butterfly fauna reveals high performance for temperate Europe. Proceedings of the Royal Society B 278: $347-355$. 
Folmer, O., Black, M., Hoeh, W., Lutz, R. \& Vrijenhoek, R. 1994. DNA primers for amplification of mitochondrial cytochrome c oxidase subunit I from diverse metazoan invertebrates. Molecular Marine Biology and Biotechnology 3: 294-299.

Garcete-Barrett, B.R. \& Hermes, M.G. 2013. The species of the genus Hypodynerus de Saussure (Hymenoptera, Vespidae, Eumeninae) occurring in Brazil. ZooKeys 296: 25-33.

Goldstein, P.Z. \& DeSalle, R. 2011. Integrating DNA barcode data and taxonomic practice: Determination, discovery, and description. BioEssays 33: 135-147.

Grehan, J.R., Parker, B.L. \& Dearborn, R.G. 1994. Description of the first and final instar of the hemlock loopers Lambdina athasaria (Walker) and Lambdina fiscellaria (Guenée) (Lepidoptera: Geometridae). Canadian Entomologist 126: 1505-1514.

Hausmann, A. \& Parra, L.E. 2009. An unexpected hotspot of moth biodiversity in Chilean northern Patagonia (Lepidoptera, Geometridae). Zootaxa 1989: 23-38.

Hausmann, A., Haszprunar, G. \& Hebert, P.D.N. 2011. DNA barcoding the geometrid fauna of Bavaria (Lepidoptera): successes, surprises and questions. PloS ONE 6: e17134. doi:10.1371/journal.pone.0017134.

Hausmann, A., Godfray, H.C.J., Huemer, P., Mutanen, M., Rougerie, R., van Nieukerken, E.J., Ratnasingham, S. \& Hebert, P.D.N. 2013. Genetic patterns in European geometrid moths revealed by the Barcode Index Number (BIN) system. PLoS ONE 8: e84518. doi:10.1371/journal.pone.0084518.

Hebert, P.D.N., Cywinska, A., Ball, S.L. \& deWaard, J.R. 2003a. Biological identifications through DNA barcodes. Proceedings of the Royal Society B 270: 313-321.

Hebert, P.D.N., Ratnasingham, S. \& deWaard, J.R. 2003b. Barcoding animal life: cytochrome c oxidase subunit 1divergences among closely related species. Proceedings of the Royal Society B 270: S96-S99.

Hebert, P.D.N., deWaard, J. \& Landry, J.-F. 2010. DNA barcodes for 1/ 1000 of the animal kingdom. Biology Letters 6: 359-362.

Hrcek, J., Miller, S.E., Quicke, D.L.J. \& Smith, M.A. 2011. Molecular detection of trophic links in a complex insect-parasitoid food web. Molecular Ecology Resources 11: 786-794.

Jinbo, U., Kato, T. \& Ito, M. 2011. Current progress in DNA barcoding and future implications for entomology. Entomological Science 14: 107-124.

Laiho, J. \& Ståhls, G. 2013. DNA barcodes identify Central-Asian Colias butterflies (Lepidoptera, Pieridae). ZooKeys 365: 175-196

Li, Q.-Q., Li, D.-Y., Ye, H., Liu, X.-F., Shi, W., Cao, N. \& Duan. Y-Q. 2011. Using COI gene sequence to barcode two morphologically alike species: the cotton bollworm and the oriental tobacco budworm (Lepidoptera: Noctuidae). Molecular Biology Reports 38: 5107-5113.

Matthews, R.W. \& González, J.M. 2004. Nesting biology of Zeta argillaceum (Hymenoptera: Vespidae: Eumeninae) in southern Florida, U. S. Florida Entomologist 87: 37-40.

Matthews, R.W. \& Matthews, J.R. 2009. Nesting behavior of Abispa ephippium (Fabricius) (Hymenoptera: Vespidae: Eumeninae): extended parental care in an Australian mason wasp. Psyche 851694, 15 p. doi: $10.1155 / 2009 / 851694$.

Miller, K.B., Alarie, Y., Wolfe, G.W. \& Whiting, M.F. 2005. Association of insect life stages using DNA sequences: the larvae of Philodytes umbrinus (Motschulsky) (Coleoptera: Dytiscidae). Systematic Entomology 30: 499-509.

Méndez-Abarca, F., Mundaca, E.A \& Vargas, H.A. 2012. First remarks on the nesting biology of Hypodynerus andeus (Packard) (Hymenoptera, Vespidae, Eumeninae) in the Azapa valley, northern Chile. Revista Brasileira de Entomologia 56: 240-243.
Mutanen, M., Hausmann, A., Hebert, P.D.N., Landry, J-F., de Waard, J.R. \& Huemer, P. 2012. Allopatry as a Gordian knot for taxonomists: Patterns of DNA barcode divergence in arctic-alpine Lepidoptera. PLoS ONE 7: e47214. doi:10.1371/journal.pone.0047214.

Nagy, Z.T, Sonet, G., Mortelmans, J., Vandewynkel, C. \& Grootaert, P. 2013. Using DNA barcodes for assessing diversity in the family Hybotidae (Diptera, Empidoidea). ZooKeys 365: 263-278.

Pérez-D'Angello, V. 1968. Insectos asociados a los nidos de Hypodynerus lachesis (Lepeletier). Revista Chilena de Entomología 6: 131-134.

Pérez-D’Angello, V. 1974. Nota sobre el nido de Hypodynerus porteri (Hymenoptera, Eumenidae). Revista chilena de Entomología 8: 147.

Pérez-D’Angello, V. 1991. Estudio morfométrico, ponderal y volumétrico de nidos de Hypodynerus chiliensis (Lepeletier). (Hymenoptera: Eumenidae). Acta Entomológica Chilena 16: 273-276.

Puillandre, N., Lambert, A., Brouillet, S. \& Achaz, G. 2011. ABGD, Automatic Barcode Gap Discovery for primary species delimitation. Molecular Ecology 21: 1864-1877.

Ratnasingham, S. \& Hebert, P.D.N. 2007. BOLD: the barcode of life data system (www.barcodinglife.org). Molecular Ecology Notes 7: 355-367.

Sears, A.W., Smiley, J.T., Hilker, M., Müller, F. \& Rank, N.E. 2001. Nesting behavior and prey use in two geographically separated populations of the specialist wasp Symmorphus cristatus (Vespidae: Eumeninae). American Midland Naturalist 145: 233-246.

Silva-Brandão, K.L., Lyra, M.L. \& Freitas, A.V.L. 2009. Barcoding Lepidoptera: current situation and perspectives on the usefulness of a contentious technique. Neotropical Entomology 38: 441-451.

Strutzenberger, P., Brehm, G. \& Fiedler, K. 2011. DNA barcoding-based species delimitation increases species count of Eois (Geometridae) moths in a well-studied tropical mountain forest by up to $50 \%$. Insect Science 18: 349-362.

Tamura, K., Peterson, D., Peterson, N., Stecher, G., Nei, M. \& Kumar, S. 2011. MEGA5: Molecular evolutionary genetic analysis using maximum likelihood, evolutionary distance, and maximum parsimony methods. Molecular Biology and Evolution 28: 2731-2739.

Teletchea, F. 2010. After 7 years and 1000 citations: Comparative assessment of the DNA barcoding and the DNA taxonomy proposals for taxonomists and non-taxonomists. Mitochondrial DNA 21: 206-226.

Valentini, A., Pompanon, F. \& Taberlet, P. 2009. DNA barcoding for ecologists. Trends in Ecology and Evolution 24: 110-117.

Vargas, H.A. 2007. Dos nuevas especies de Iridopsis Warren (Lepidoptera, Geometridae) del norte de Chile. Revista Brasileira de Entomologia 51: $138-141$.

Vargas, H.A. 2014. First host plant records for Iridopsis hausmanni Vargas (Lepidoptera, Geometridae) in the coastal valleys of northern Chile. Revista Brasileira de Entomologia 58: 95-97.

Vargas, H.A. \& Parra, L.E. 2013. Estados inmaduros de Iridopsis parrai (Lepidoptera: Geometridae). Revista Colombiana de Entomología 39: 105112.

Vargas, H.A., Parra, L.E. \& Hausmann, A. 2005. Macaria mirthae: nueva especie de Ennominae (Lepidoptera: Geometridae) de Chile. Neotropical Entomology 34: 571-576.

West-Eberhard, M.J. 2005. Behavior of the primitively social wasp Montezumia cortesioides Willink (Vespidae, Eumeninae) and the origins of the vespid sociality. Ethology Ecology and Evolution 17: 201-215.

Willink, A. 1970. Revisión del género Hypodynerus Saussure (Hym., Eumenidae). I Grupo de Hypodynerus humeralis (Hal.). Acta Zoológica Lilloana 25: 227-278. 